\title{
A NEW GENUS OF MEGALONYCHIDAE (MAMMALIA, XENARTHRA) FROM THE LATE MIOCENE OF ARGENTINA
}

\author{
DIEGO BRANDONI \\ Laboratorio de Paleontología de Vertebrados, Centro de Investigaciones Científicas y Transferencia de Tecnología a la \\ Producción (CICYTTP-CONICET), Materi y España, 3105 Diamante, Entre Ríos, Argentina. dbrandoni@cicyttp.org.ar
}

\begin{abstract}
The present report describes a new genus of Megalonychidae from the Late Miocene of Entre Ríos Province, Argentina, based on a detailed reanalysis of the remains on which "Ortotherium" brevirostrum (Xenarthra, Tardigrada, Megalonychidae) was originally described. "O." brevirostrum differs from $O$. laticurvatum (type species of the genus) and Ortotherium sp. in: (i) absence of a markedly concavity on the lateral wall of the dentary in "O." brevirostrum, (ii) convexity of the ventral margin of the dentary, (iii) angle between the anterior margin of the coronoid process and the alveolar plane, (iv) length of the diastema, (v) outline of the alveolus of the caniniform, (vi) outline of the molariforms, and (vii) presence of apicobasal grooves extending on the lingual and vestibular surfaces of the molariforms ( $\mathrm{m} 1$ and $\mathrm{m} 2)$ in "O." brevirostrum. The presence of these differences suggests that $O$. laticurvatum and "O." brevirostrum should not be in the same genus. In addition, "O." brevirostrum cannot be accommodated within an existing genus; hence the determination of a new genus of Megalonychidae is justified. The new taxon shows some features (e.g. shape of the alveolus of the caniniform, presence of apicobasal grooves in the molariforms) that are present in some genera of Megalonychidae from the Pleistocene of Central America and Antilles (i.e. Neocnus and Parocnus). This similarity could imply that the genera from the Pleistocene of Central America and Antilles and the new taxon are related.
\end{abstract}

Key words: Tardigrada, South America, Central America, ground sloths, diversity.

RESUMO - O presente trabalho descreve um novo gênero de Megalonychidae do Mioceno superior da Província de Entre Ríos, Argentina, resultado de uma nova análise detalhada dos restos "Ortotherium" brevirostrum (Xenarthra, Tardigrada, Megalonychidae) originalmente descritos. "O." brevirostrum difere de O. laticurvatum (espécie tipo do gênero) e $O$. sp. em: (i) a ausência de uma acentuada concavidade da parede lateral do dentário em "O." brevirostrum, (ii) convexidade da margem ventral do dentário, (iii) ângulo entre a linha alveolar margem anterior do processo coronoide, (iv) comprimento do diastema, (v) um contorno alveolar do caniniforme, (vi) contorno dos molariformes, e (vii) presença de sulcos apicobasal que se prolongam sobre os lados lingual e labial dos molariformes ( $\mathrm{m} 1 \mathrm{e} \mathrm{m} 2)$ em "O." brevirostrum. A presença destas diferenças sugere que O. laticurvatum e "O." brevirostrum não deveriam estar no mesmo gênero. Além disso, “O.” brevirostrum não pode pertencer a este gênero, logo a determinação de um novo gênero de Megalonychidae é justificada. O novo táxon mostra algumas características (por exemplo, a forma dos alvéolos com formato caniniforme e a presença de sulcos apicobasal nos molariformes) que estão presentes em alguns gêneros de Megalonychidae do Pleistoceno da América Central e Antilhas (i.e. Neocnus e Parocnus). Essas semelhanças poderiam indicar que os gêneros do Pleistoceno da América Central e Antilhas e o novo táxon estão relacionados.

Palavras-chave: Tardigrada, América do Sul, América Central, preguiças, diversidade.

\section{INTRODUCTION}

The clade Megalonychidae (Xenarthra, Tardigrada) is known from the Oligocene of Santa Cruz Province, Argentina (i.e. Deseadognathus Carlini \& Scillato-Yané, 2004) and Bolivia (Pujos \& De Iuliis, 2007) as well as from the present, represented by the extant sloth Choloepus Illiger, 1811 (see White \& MacPhee, 2001; Gaudin, 2004; but see Carlini \& Scillato-Yané, 2004 for the systematic allocation of the other extant sloth, i.e. Bradypus Linnaeus, 1758). Although the most important fossil records of this clade are those from the Quaternary of Central America and the Antilles (e.g. Megalocnus Leidy, 1868, Acratocnus Anthony, 1916,
Parocnus Miller, 1929, Neocnus Arredondo, 1961, Paulocnus Hooijer, 1962; see Matthew \& Paula Couto, 1959; White \& MacPhee, 2001) and North America (e.g. Megalonyx Harlan, 1825, Pliometanastes Hirschfeld \& Webb, 1968; see Hirschfeld \& Webb, 1968; White \& MacPhee, 2001; McDonald et al., 2013a), in South America the clade is mainly recorded from the Neogene and Quaternary of Argentina (see below), the Quaternary of Brazil (i.e. Ahytherium Cartelle, De Iuliis \& Pujos, 2008; Australonyx De Iuliis, Pujos \& Cartelle, 2009), the Pleistocene of Peru (i.e. Diabolotherium Pujos, De Iuliis, Argot \& Werdelin, 2007; see Pujos et al., 2007; Shockey et al., 2009; see also Pujos et al., 2011 for the systematic allocation of Diabolotherium), and the Pleistocene of Venezuela (i.e. 
Megistonyx oreobios McDonald, Rincón \& Gaudin, 2013; see McDonald et al., 2013b). In Argentina, besides the record of Deseadognathus riggsi Carlini \& Scillato-Yané, 2004, from the Deseado Formation, Megalonychidae were recorded from the Santa Cruz Formation (late Early Miocene) of Santa Cruz Province (i.e. Eucholoeops Ameghino, 1887; Scott, 1903-1904; Scillato-Yané, 1986; Tauber, 1997; Bargo et al., 2009), the Arroyo Chasicó Formation (Late Miocene) of Buenos Aires Province (i.e. Protomegalonyx chasicoensis Scillato-Yané, 1977; see Scillato-Yané, 1977; Brandoni, 2009), the Río Negro Formation (Scillato-Yané et al., 1976), the "Conglomerado osífero" (ossiferous conglomerate) or "Mesopotamiense" (Late Miocene) within the Ituzaingó Formation, Entre Ríos Province (Carlini et al., 2000; Cione et al., 2000; Brandoni, 2010, 2011, 2013a), and from the Pleistocene of Buenos Aires Province (Kraglievich, 1930).

Several authors have studied the Megalonychidae from the "Conglomerado osífero" (e.g. Ameghino, 1883, 1885, 1891a; Kraglievich ,1922, 1923a, b, c, 1925, 1926a, b; Bordas, 1942; Scillato-Yané, 1980); however, these ground sloths were not usually considered in recent studies due in large part to the poor preservation and fragmentary nature of their remains (Brandoni, 2010). The most recent contributions on Megalonychidae from the "Conglomerado osífero" are those by Brandoni $(2008,2010,2011)$ who actualized systematic aspects of Ortotherium Ameghino, 1885, Pliomorphus Ameghino, 1885, Menilaus Ameghino, 1891, Amphiocnus Kraglievich, 1922, Protomegalonyx Kraglievich, 1925, Megalonychops Kraglievich, 1926, and Paranabradys Scillato-Yané 1980.

With respect to Ortotherium, several species were erected by Florentino Ameghino at the end of the 19th century: $O$. laticurvatum Ameghino, 1885, O. robustum Ameghino 1891, O. schlosseri Ameghino, 1891, and O. seneum Ameghino, 1891 (see Ameghino, 1891a). In addition, Bordas (1942) described O. scrofum Bordas, 1942, and O. brevirostrum Bordas, 1942 (Cione et al., 2000; Carlini et al., 2000; Brandoni 2010, 2011, 2013a). Brandoni (2010) considered $O$. laticurvatum as the only valid species for the genus, with $O$. schlosseri, $O$. seneum, $O$. scrofum, being junior synonyms of $O$. laticurvatum. In addition, Brandoni (2010) considered "Ortotherium" brevirostrum not congeneric with O. laticurvatum suggesting that "Ortotherium" brevirostrum may be the type species of a new genus; however, Brandoni (2010) did not nominate such a genus.

The present report describes a new genus of Megalonychidae based on a detailed reanalysis of the remains on which "Ortotherium" brevirostrum was originally described.

Institutional abbreviations. MACN Pv, Colección Paleontología Vertebrados del Museo Argentino de Ciencias Naturales "Bernardino Rivadavia", Buenos Aires, Argentina; MLP, Museo de La Plata, La Plata, Argentina.

Other abbreviations. c, caniniform; Ma, millions of years ago; m1-m3, lower molariform 1-3; po, posterolateral opening of mandibular canal.

\section{GEOLOGICAL SETTING}

In Entre Ríos Province, Argentina, remains of fossil vertebrates were collected from the lower levels of the Ituzaingó Formation, particularly from a basal level, informally known as "Mesopotamiense" or "Conglomerado osífero" (Frenguelli, 1920); recently these levels were considered as the lower member of the Ituzaingó Formation (Brunetto et al., 2013). The Ituzaingó Formation extends from the city of Ituzaingó in Corrientes Province where the type profile was originally described, to the north of Paraná, the capital of Entre Ríos Province (Figure 1A). The "Mesopotamiense" outcrops discontinuously from cliffs along the Paraná River, from the vicinity of the city of Paraná to the locality of Hernandarias (Figure 1B). The "Mesopotamiense" (Figure 2) is clearly visible in places where the discordance between the underlying Paraná Formation, marine in origin, and the sandy-clayey and conglomerate levels of the Ituzaingó Formation becomes evident. Its thickness is variable, and it is characterized by levels with fine quartz gravel, clay and chalcedony clasts, as well as abundant bones and teeth, frequently fragmented and disassociated, and mostly corresponding to continental and marine vertebrates. Cione et al. (2000) referred the "Conglomerado osífero" to the Huayquerian (Late Miocene) of the South America Stage/ Age system. Recently, Brandoni (2013b) analyzed a complete and updated list of fossil continental mammals recorded in the "Mesopotamiense" and proposed an affinity of the "Mesopotamiense" with the Chasicoan fauna of Buenos Aires Province, and considered that the beginning of the deposition of the "Mesopotamiense" begins in the early Late Miocene (i.e. Tortonian Stage/Age, Gradstein et al., 2012).

\section{SYSTEMATIC PALEONTOLOGY}

Superorder XENARTHRA Cope, 1889

Order TARDIGRADA Latham \& Davies in Forster, 1795 Family MEGALONYCHIDAE Gervais, 1855

Mesopotamocnus gen. nov.

1885 Ortotherium in part. Ameghino, p. 111-113.

Type species. Mesopotamocnus brevirostrum (Bordas, 1942) comb. nov.

Derivation of name. Mesopotam, from its geographic provenance: Mesopotamia (from Greek meaning between rivers; ocnus from latinized Greek meaning slowness).

Geographic and stratigraphic provenances. In the vicinity of the city of Paraná, Entre Ríos Province (Argentina; Figure 1B) within the "Conglomerado osífero" or "Mesopotamiense" (lower member of Ituzaingó Formation, see Brunetto et al., 2013; Figure 2). Tortonian Stage/Age (Late Miocene) (Cione et al., 2000; Brandoni, 2010, 2011, 2013b).

Diagnosis. Larger than Deseadognathus, slightly larger than Eucholoeops, similar in size to Ortotherium and 


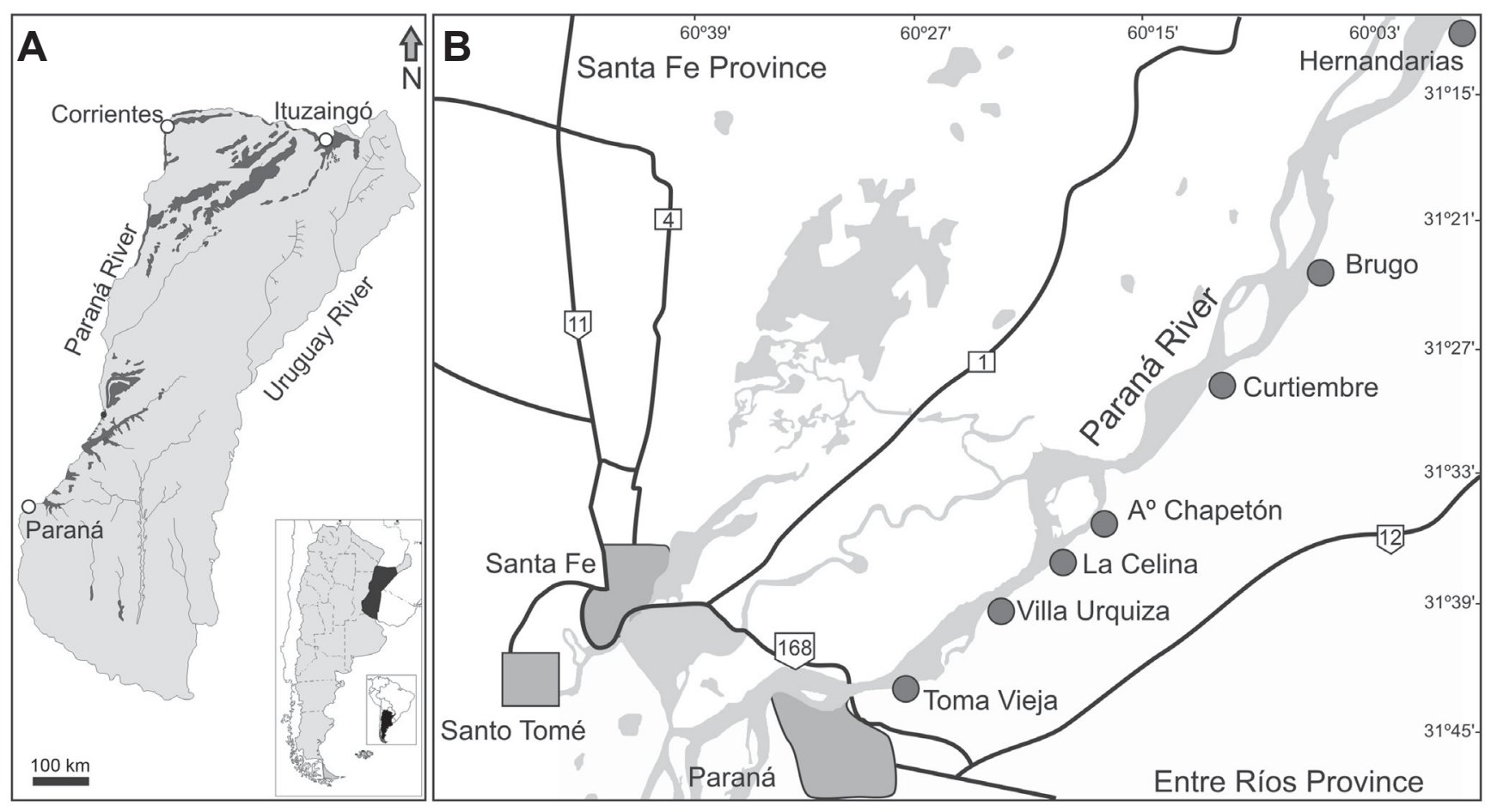

Figure 1. Map of the Ituzaingó Formation and the "Mesopotamiense". A, location of the Ituzaingó Formation at Mesopotamia, Argentina (dark grey areas); B, principal localities where the "Conglomerado osifero" is exposed (grey circles) (modified from Brunetto et al., 2013).

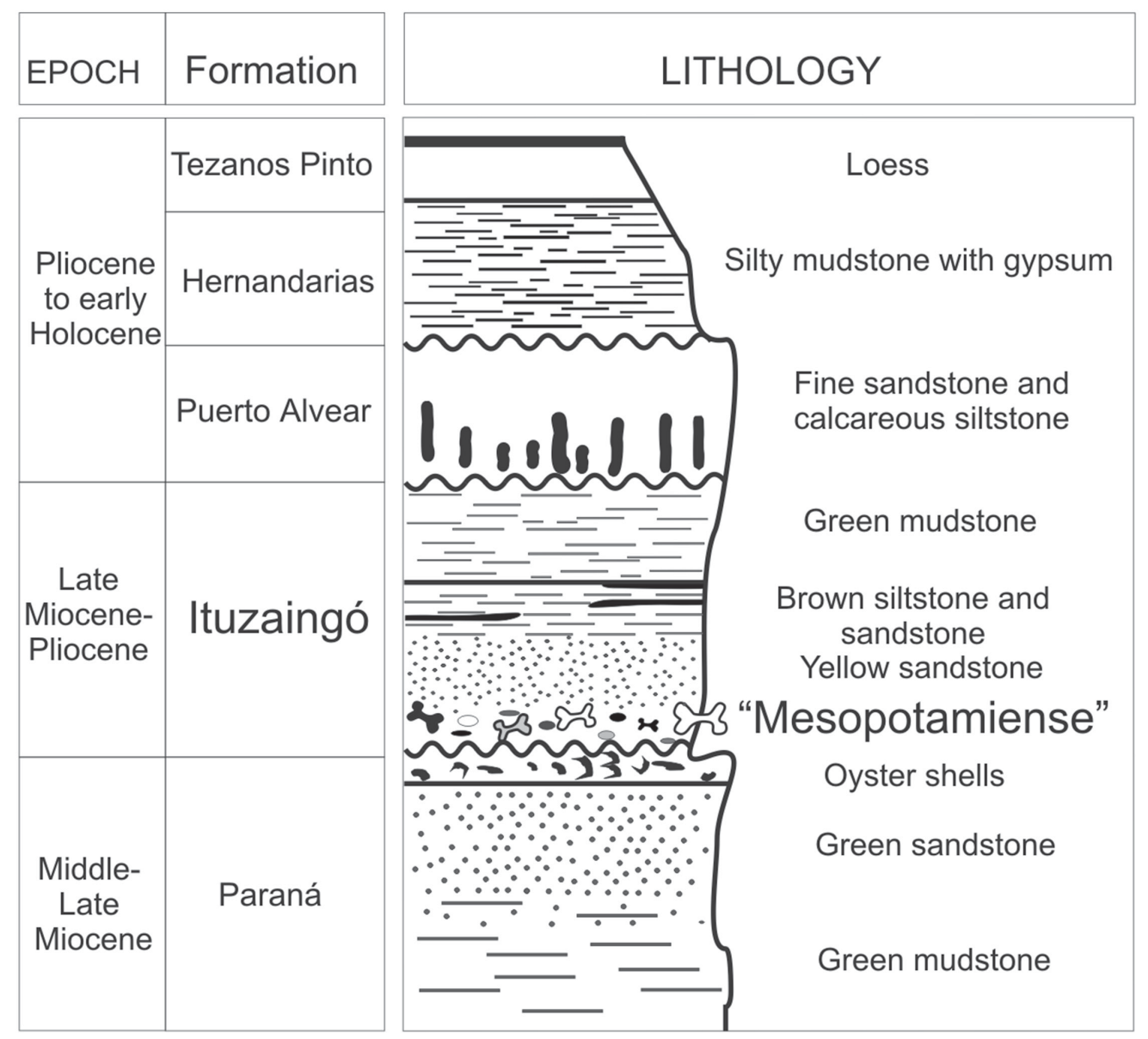

Figure 2. Generalized stratigraphic profile of the area of Paraná, Entre Ríos Province, Argentina (modified from Aceñolaza, 1976; Brandoni, 2006). 
Paranabradys, and smaller than Megalonyx, and Megalocnus. Posterolateral opening of mandibular canal on lateral margin of base of coronoid process, as in Eucholoeops, Paranabradys, and Megalocnus. As in Ortotherium, anterior margin of the coronoid process lateral to midpoint of $\mathrm{m} 3$, more anterior than in Eucholoeops and Paranabradys, and more posterior than in Megalocnus, Megalonyx, and Pliometanastes. As in Ortotherium, posterior margin of mandibular symphysis ventromedial to c-m1 diastema; slightly anterior to the plane of the $\mathrm{m} 1$ in Parocnus and Deseadognathus, ventromedial to $\mathrm{m} 1-\mathrm{m} 2$ interval in Megalocnus; ventromedial to the caniniform in Megalonyx and Pliometanastes. As in Parocnus, alveolus of caniniform meniscoid in cross-section; subcircular in Ortotherium; larger and more oval in Megalonyx; larger and meniscoid in Megalocnus; subtriangular in Deseadognathus and Eucholoeops; $\mathrm{m} 1$ trapezoidal in crosssection; subrectangular in Megalonyx and Megalocnus. m2 trapezoidal in cross-section, and $\mathrm{m} 3$ suboval in cross-section; $\mathrm{m} 2$ subtrapezoidal and $\mathrm{m} 3$ nearly oval in Megalonyx and Megalocnus. As in some specimens of Neocnus, $\mathrm{m} 1$ and $\mathrm{m} 2$ with apicobasal grooves extending on their lingual and vestibular surfaces. Occlusal surface of $\mathrm{m} 1$ and $\mathrm{m} 2$ with two crests (lophids) along the mesial and distal edge of each tooth.

$$
\begin{gathered}
\text { Mesopotamocnus brevirostrum (Bordas, 1942) } \\
\text { comb. nov. } \\
\text { (Figures 3A-C) }
\end{gathered}
$$

1942 Ortotherium brevirostrum Bordas, pl. 2, p.176.

Holotype. MACN Pv 13656, type of Ortotherium brevirostrum Bordas, 1942, incomplete right dentary that preserves the $\mathrm{m} 1$ and $\mathrm{m} 2$.

Geographic and stratigraphic provenances. In the vicinity of the city of Paraná, Entre Ríos Province (Argentina; Figure 1B) within the "Conglomerado osífero" or "Mesopotamiense" (lower member of Ituzaingó Formation, see Brunetto et al., 2013; Figure 2). Tortonian Stage/Age (Late Miocene) (Cione et al., 2000; Brandoni, 2010, 2011, 2013b).

Diagnosis. As for the genus by monotypy.

Description. MACN Pv 13656 is an almost complete right dentary that preserves the $\mathrm{m} 1$ and $\mathrm{m} 2$, although it is missing the angular process, condyloid process, caniniform, and $\mathrm{m} 3$. The preserved length is $115 \mathrm{~mm}$, and maximum depth (at the level $\mathrm{m} 2-\mathrm{m} 3$ ) is $55 \mathrm{~mm}$, being similar in size to most of the specimens referred to Ortotherium and Paranabradys (see Brandoni, 2010, tab. 1).

The ventral margin of the dentary is very convex both transversely and anteroposteriorly; whereas in Ortotherium laticurvatum and Ortotherium sp. (see Brandoni, 2010), it is anteroposteriorly less convex; and in Eucholoeops sp. it is nearly straight anterior to the $\mathrm{m} 3$ (Bargo et al., 2009, fig. 2F). As in the specimens referred to Ortotherium, Eucholoeops fronto Ameghino, 1891 (see Ameghino, 1891b), and Megalocnus rodens Leidy, 1868, among others, the dorsoventral height of the horizontal ramus decreases anteriorly to $\mathrm{m} 3$.
In Mesopotamocnus brevirostrum comb. nov., the posterolateral opening of the mandibular canal is at the base of the coronoid process, almost at the same level of the alveolar series, and faces nearly laterally (Figure 3A). In Megalonyx jeffersonii Desmarest, 1822, and Paranabradys vucetichae Scillato-Yané, 1980 (see Scillato-Yané, 1980, fig. 1.1), the position of the opening resembles $M$. brevirostrum comb. nov. In Ortotherium sp., Acratocnus odontrigonus Anthony, 1916, and Neocnus dousman MacPhee, White \& Woods, 2000, the posterolateral opening of the mandibular canal is on the lateral side of the horizontal ramus (Anthony, 1926, pl. XXXVIII; MacPhee et al., 2000, figs. 8B, 12B; Brandoni, 2010, fig. 3A).

As in Ortotherium, in Mesopotamocnus brevirostrum comb. nov. the anterior margin of the coronoid process is lateral to the midpoint of m3 (Figures 3A-C). In Paranabradys vucetichae (see Scillato-Yané, 1980, fig. 1.1) and Eucholoeops sp. (Bargo et al., 2009, fig. 2F), it is posterior to $\mathrm{m} 3$, so that the entire tooth is visible in lateral view. In Megalonyx jeffersonii, Megalocnus rodens, Parocnus browni (Matthew, 1931), and Pliometanastes protistus Hirschfeld \& Webb, 1968, it is lateral to $\mathrm{m} 3$, obscuring it in lateral view (see Gaudin, 2004, character 40). In Mesopotamocnus brevirostrum comb. nov., the anterior margin of the coronoid process forms a $136^{\circ}$ angle with the alveolar plane; whereas the angle is $107^{\circ}$ in Ortotherium sp. (Brandoni, 2010).

In occlusal view at tooth row level (Figure 3B), the lateral wall of the horizontal ramus is markedly convex, without the concave dorsal portion (i.e. the buccinator fossa) between the caniniform and the first molariform that is present in most Megalonychidae, including Ortotherium laticurvatum, Megalocnus rodens (see Matthew \& Paula Couto, 1959, pl. 8), Parocnus spp. (see Matthew \& Paula Couto, 1959, pl. 30), Megalonyx jeffersonii (see Stock, 1925, pl. 17) and Pliometanastes protistus (see Hirschfeld \& Webb, 1968, fig. 14). Although the left dentary is not preserved, its preserved portion suggests that the margin of the mandibular symphysis seems to be U-shaped (Figure 3B). As in Ortotherium laticurvatum, the posterior margin of the mandibular symphysis of Mesopotamocnus brevirostrum comb. nov. is located ventromedial to the c-m 1 diastema (Figure 3B); whereas in Parocnus browni and Deseadognathus riggsi, the symphysis is slightly anterior to the $\mathrm{m} 1$ (Mathew \& Paula Couto, 1959, fig. 2C; Carlini \& Scillato-Yané, 2004, fig. 2D); it is ventromedial to the m1-m2 septum in Megalocnus rodens (see Mathew \& Paula Couto, 1959, fig. 1C), and in Megalonyx jeffersonii and Pliometanastes protistus (see Hirschfeld \& Webb, 1968, fig. 14) reaches the plane of the middle of the caniniform.

The lower dental series of the Megalonychidae comprises four teeth; a diastema is present between the first tooth (generally termed caniniform) and the rest of the teeth (molariforms). The lower dental tooth row of Mesopotamocnus brevirostrum comb. nov. is $65 \mathrm{~mm}$ in length, the outline of the caniniform alveolus is oval to meniscoid, with its mesiodistal length twice as long as the vestibulolingual width (length, $12 \mathrm{~mm}$; width $7 \mathrm{~mm}$ ), and the main axis nearly aligned to the tooth row (Figure 3B). In Ortotherium laticurvatum, 
A

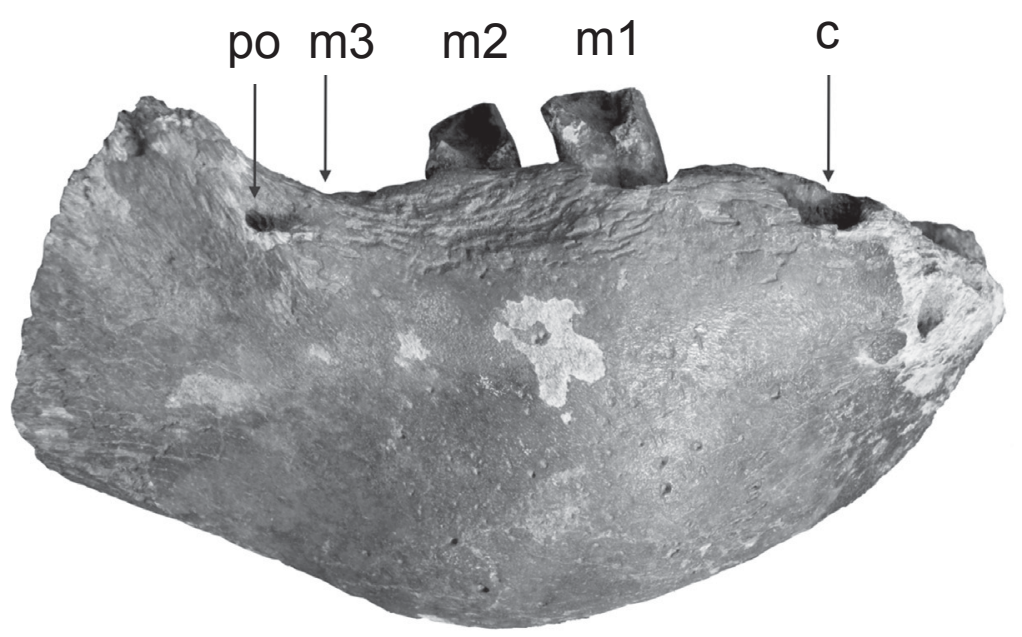

B
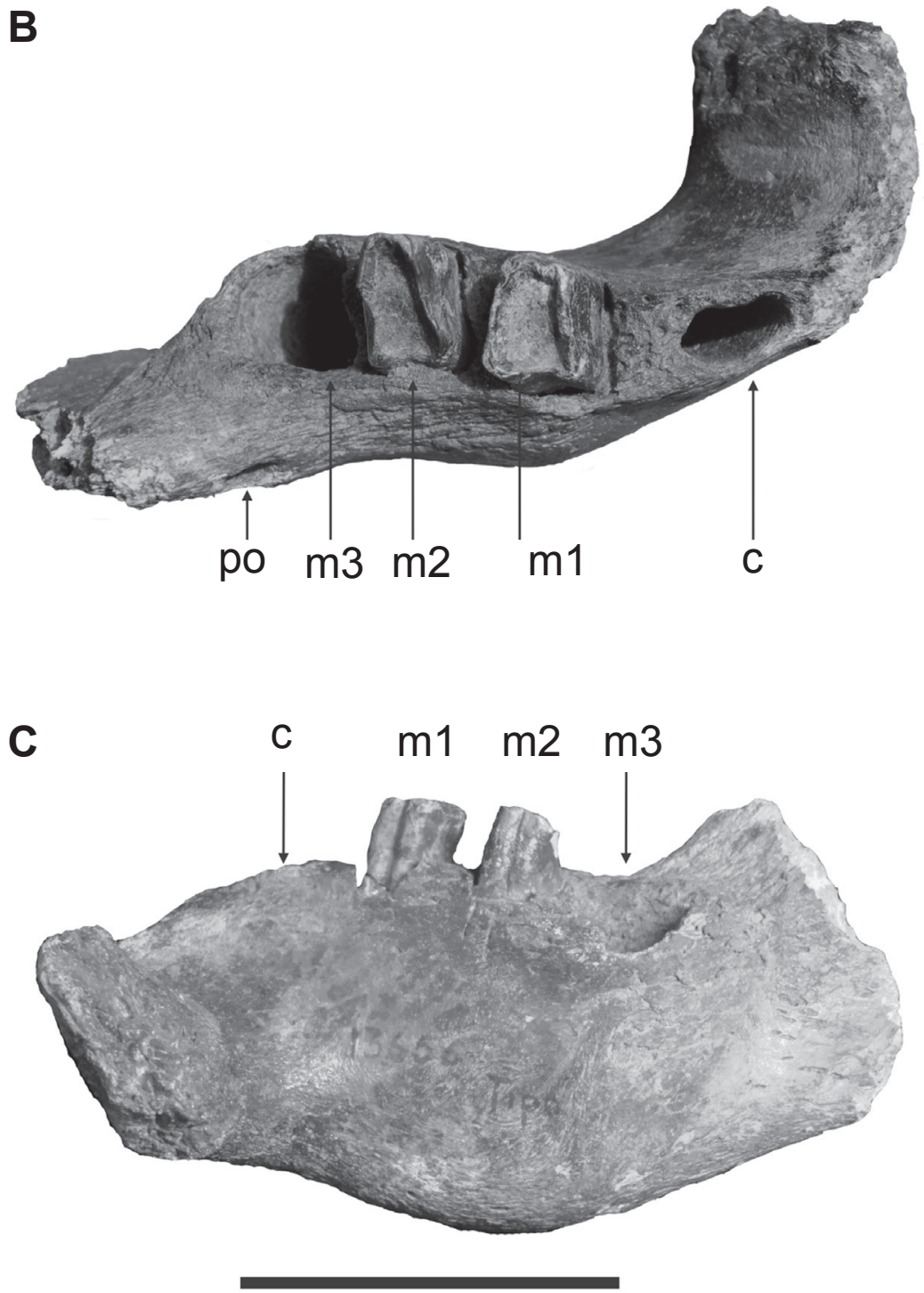

Figure 3. Right dentary of Mesopotamocnus brevirostrum (Bordas, 1942) comb. nov. (MACN Pv 13656). A, lateral view; B, oclusal view; C, medial view. Abbreviations: c, caniniform; m1-m3, lower molariform 1-3; po, posterolateral opening of mandibular canal. Scale bar $=50 \mathrm{~mm}$. 
the caniniform is subcircular in cross-section; in Megalonyx jeffersonii is ovate, often with a marked posteromedial bulge. In Parocnus browni (see Mathew \& Paula Couto, 1959, fig. $2 \mathrm{C}$ and pl. 30), the outline of the alveolus is similar to that of Mesopotamocnus brevirostrum comb. nov. In Megalocnus rodens, it is meniscoid in outline with its major axis nearly oblique respect the tooth row (Matthew \& Paula Couto, 1959, pl. 9). In Deseadognathus riggsi and Eucholoeops fronto it is subtriangular in section. The diastema is relatively short $(8.6 \mathrm{~mm})$ compared with the diastema of Ortotherium (15-20 $\mathrm{mm}$; Brandoni, 2010).

The $\mathrm{m} 1$ is rectangular to trapezoidal in section (lingual length, $9 \mathrm{~mm}$; vestibular length $12 \mathrm{~mm}$; width, $18 \mathrm{~mm}$ ). The occlusal surface is formed by two crests (lophids) along the mesial and distal edge of the tooth; these crests are lingually connected (Figures 3B,C). As in some specimens of Neocnus (see McAfee, 2011), this tooth has apicobasal grooves extending on their lingual and vestibular surfaces (Figures $3 \mathrm{~A}-\mathrm{C})$; with the lingual groove deeper than the vestibular one. In Ortotherium laticurvatum, the $\mathrm{m} 1$ is subtriangular in section and with rounded edges; in Megalocnus rodens, the $\mathrm{m} 1$ is subrectangular in section, and in Parocnus browni the section is similar to that of Mesopotamocnus brevirostrum comb. nov..

The $\mathrm{m} 2$ also presents a trapezoidal outline (lingual length, $8 \mathrm{~mm}$; vestibular length $11.5 \mathrm{~mm}$; width, $15 \mathrm{~mm}$ ). As in the $\mathrm{m} 1$, the $\mathrm{m} 2$ has the vestibulolingual lophids and the apicobasal grooves on lingual and vestibular surfaces (Figures 3B,C). In Ortotherium laticurvatum, the $\mathrm{m} 2$ is oval to trapezoidal, with the long axis oriented transversely relative to the sagittal plane. In Megalocnus rodens and Parocnus browni, the $\mathrm{m} 2$ is subtriangular in section and with rounded edges.

The alveolus of the $m 3$ is suboval in outline with the long axis anteroposteriorly inclined with respect to the sagittal plane (length, $14 \mathrm{~mm}$; width, $18 \mathrm{~mm}$ ). The interalveolar septa separating the alveoli of the three molariforms are not very thin (Figure 3A); the septa are thin in Ortotherium.

\section{DISCUSSION}

"Ortotherium" brevirostrum was originally described as a Nothrotheriinae, a group that was included in Megalonychidae (see Bordas, 1942, p. 174,176); however, the genus Ortotherium is currently considered as a Megalonychidae, without assignment to a particular clade (e.g. Ortotheriinae, Megalocninae or Megalonychinae) (see Brandoni, 2011). In addition, most of the genera and species that were traditionally viewed as nothrotheres are considered members of Nothrotheriinae (e.g. Nothrotherium Lydekker, 1889, Nothropus Burmeister, 1882, Pronothrotherium Ameghino, 1907, Nothrotheriops Hoffstetter, 1954, Mionothropus De Iuliis, Gaudin \& Vicars, 2011) or as basal Megatherioidea (e.g. Hapalops Ameghino, 1887, Schismotherium Ameghino, 1887, Xyophorus Ameghino, 1887, Pelecyodon Ameghino, 1891) (Gaudin, 2004; De Iuliis et al., 2011; Pujos et al., 2011).

"Ortotherium" brevirostrum differs from Ortotherium laticurvatum (Figures 4A,B) and Ortotherium sp. (Figures
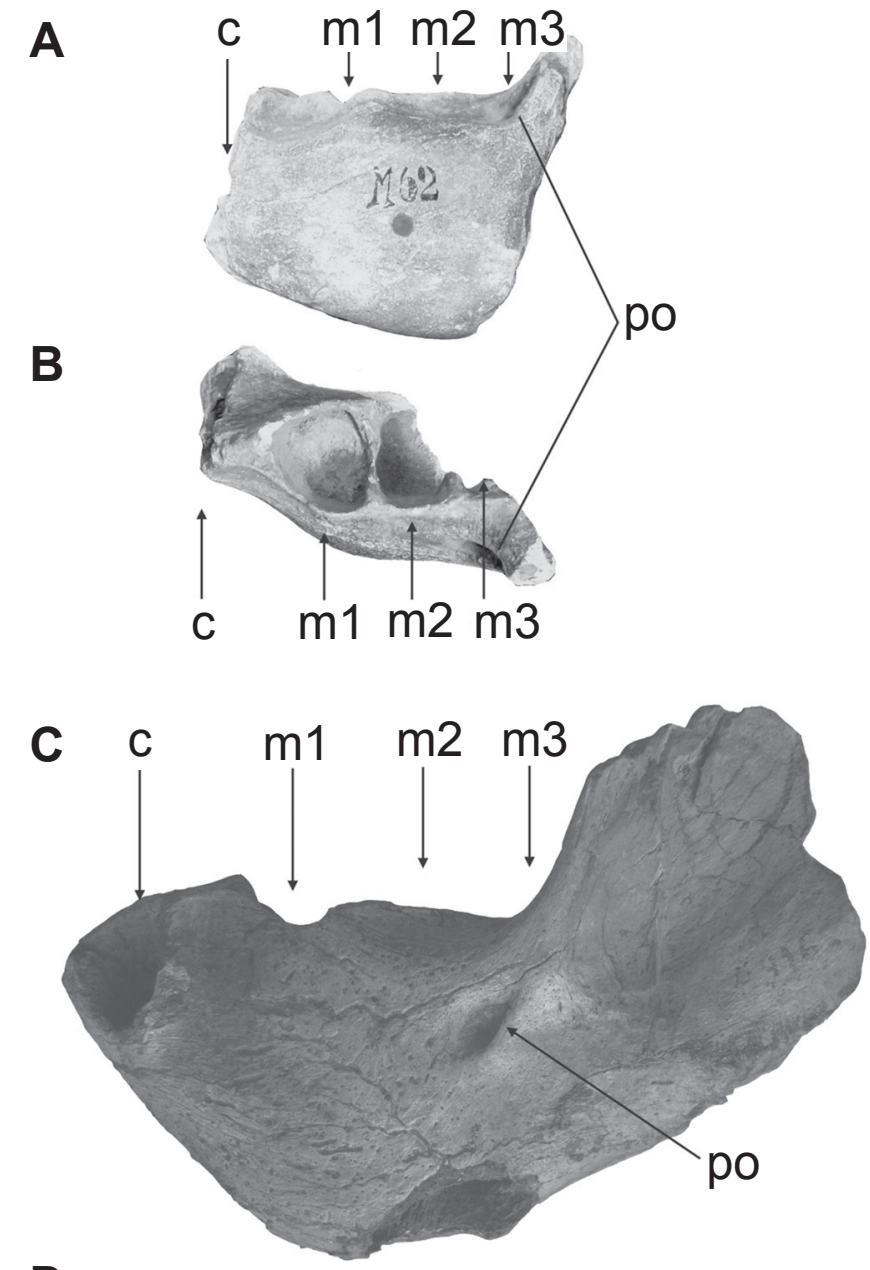

D

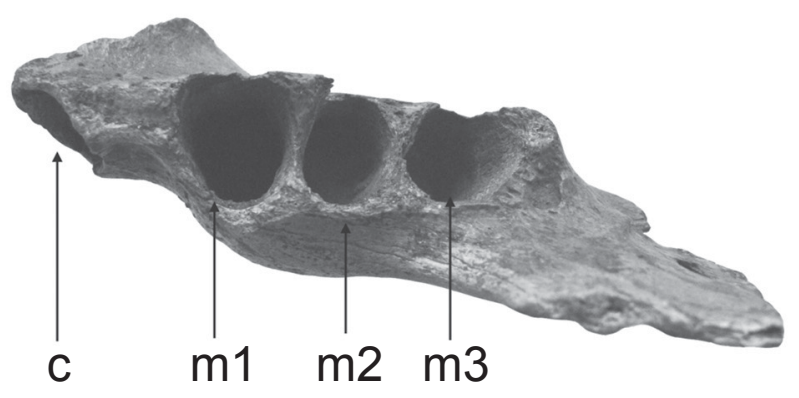

Figure 4. Dentaries of Ortotherium Ameghino, 1885. A-B, left dentary of Ortotherium laticurvatum Ameghino, 1885 (MLP M 62, cast of type of O. laticurvatum); C,D, left dentary of Ortotherium sp. (MACN Pv 8916). A,C, lateral view; B,D, oclusal view. Abbreviations: c, caniniform; m1-m3, lower molariform 1-3; po, posterolateral opening of mandibular canal. Scale bar $=50 \mathrm{~mm}$

4C,D) in several features: (i) absence of a markedly concavity on the lateral wall of the dentary in "O." brevirostrum, (ii) convexity of the ventral margin of the dentary, (iii) angle between the anterior margin of the coronoid process and the alveolar plane, (iv) length of the diastema, (v) outline of the alveolus of the caniniform, (vi) outline of the molariforms, and (vii) presence of apicobasal grooves extending on the lingual and vestibular surfaces of the molariforms in 
"O." brevirostrum. As noted by Brandoni (2010), the presence of these differences suggests that $O$. laticurvatum and "O." brevirostrum should not be in the same genus. In addition, and based on currently available evidence, "O." brevirostrum cannot be accommodated within an existing genus, hence the determination of a new genus of Megalonychidae (Mesopotamocnus nov. gen.) is justified. It is important to remark that given the present state of knowledge, it is not possible to elucidate synonymies between the Megalonychidae from the "Mesopotamiense" based on postcranial remains to those determined on cranial ones. Thus, it is not possible to refer MACN Pv 13656 (type of $M$. brevirostrum comb. nov.) to any of the genera and species described on postcranial remains (e.g. Torcellia, Protomegalonyx, Amphiocnus).

Mesopotamocnus brevirostrum comb. nov. shows features that clearly resemble those of megalonychids (e.g. presence of a relatively robust caniniform, presence of diastema between $\mathrm{c} 1$ and $\mathrm{m} 1$ ); however, the presence of apicobasal grooves on the lingual and vestibular surfaces of the molariforms ( $\mathrm{m} 1$ and $\mathrm{m} 2$ ) it is not common among Megalonychidae, apicobasal grooves are present in the molariforms of some specimens of Neocnus (McAfee, 2011), but resembles the morphology of the molariforms of Nothrotheriidae (see De Iuliis et al.,
2011). According to De Iuliis et al. (2011), the presence of apicobasal grooves on molariform teeth is a synapomorphy of Nothrotheriidae (represented by Thalassocnus Muizon \& McDonald, 1995, Mionothropus, Pronothrotherium, Nothrotherium, and Nothrotheriops in the analysis performed by De Iuliis et al., 2011). In addition, this feature is also present in the Nothrotheriinae "Xyophorus" bondesioi Scillato-Yané, 1979, and "Xyophorus" villarroeli Saint-André, 1996 (Brandoni, 2014).

In most Megalonychidae, the caniniform is relatively robust and it is separated from the molariforms by a diastema. In Diabolotherium nordenskioldi (Kraglievich, 1926), originally described as a Megalonychidae from the Pleistocene of Peru, the alveolus of the first lower tooth resembles that of the Megatheriinae and the diastema is absent (see Kraglievich, 1926b; Pujos et al., 2007, fig. 6B; Shockey, 2009, fig. 4.1). However, recently and based on the shape of the teeth, Pujos et al. (2011) considered that Diabolotherium is neither a nothrotheriid nor a megalonychid. In some Nothrotheriinae (e.g. Pronothrotherium typicum Ameghino, 1907, Mionothropus cartellei De Iuliis, Gaudin \& Vicars, 2011) and some basal megatherioids (e.g. Hapalops), the caniniform is reduced, subcircular or suboval in outline, and separated from the molarifoms by a diastema. As was
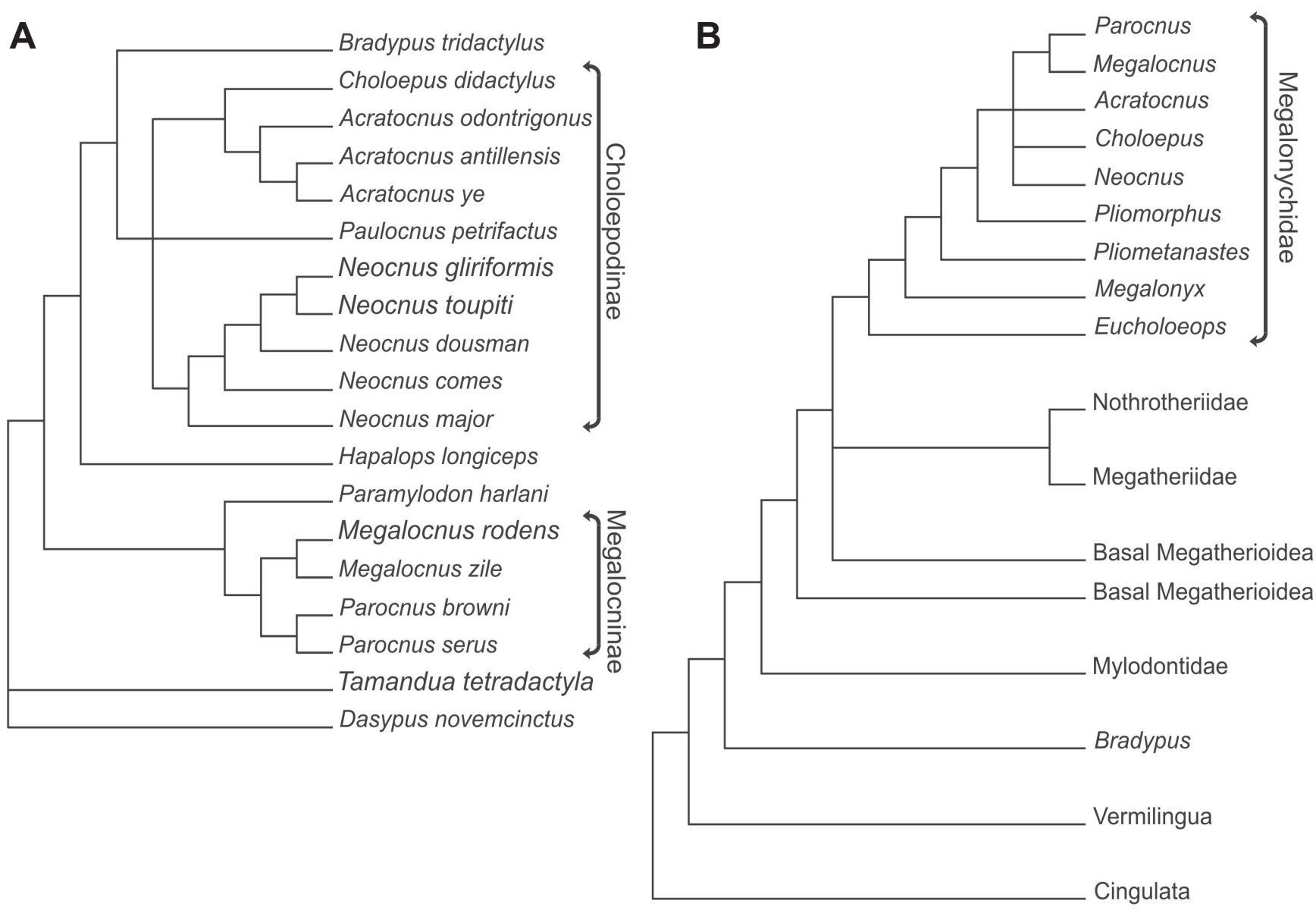

Figure 5. Cladograms showing relationships among Megalonychidae. A, modified from White \& MacPhee (2001); B, modified from Gaudin (2004). 
indicated, in Mesopotamocnus brevirostrum comb. nov. the alveolus of the caniniform is oval to meniscoid in outline, with anteroposterior length twice that of the vestibulolingual width, resembling the condition of some Megalonychidae from Central America (see below).

Mesopotamocnus brevirostrum comb. nov. shows some features (e.g. shape of the alveolus of the caniniform, presence of apicobasal grooves in the molariforms) that are present in some genera of Megalonychidae recorded from the Pleistocene of Central America and Antilles. $M$. brevirostrum comb. nov. shares with Neocnus the shape of molariforms (presence of apicobasal grooves) and with Parocnus the shape of the alveolus of the caniniform. This similarity could imply that the genera from the Pleistocene of Central America and Antilles and M. brevirostrum comb. nov. are related.

Currently, based on cladistic analyses, Parocnus is considered the sister group to Megalocnus (White \& MacPhee, 2001; Gaudin, 2004). White \& MacPhee (2001) proposed a diphyletic origin for the Antillean megalonychids, with the clade Megalocninae formed by Megalocnus and Parocnus and the clade Choloepodinae represented by Choloepus, Acratocnus, Paulocnus, and Neocnus (Figure 5A). On the other hand, Gaudin (2004) proposed a close relationship between the extant Choloepus and the Antillean Megalonychidae with a clade formed by Parocnus, Megalocnus, Acratocnus, Choloepus and Neocnus (Figure 5B). Whether Mesopotamocnus brevirostrum comb. nov. is the sister group to Megalocninae (sensu White \& MacPhee, 2001) or it is related to Choloepodinae (sensu White \& MacPhee, 2001) cannot be tested with the available information since it is necessary to have more complete specimens of M. brevirostrum comb. nov. It is important to remark that in the early 19th Century, Kraglievich (1923b) had already considered a close relationship between the Megalonychidae from the Neogene of Entre Ríos Province, Argentina, with those from the Pleistocene of Central America and Antilles (e.g. Megalocnus).

Finally, given that most of the species of Megalonychidae from the "Mesopotamiense" are endemic, the taphonomical context of the unit (e.g. fragmented and disassociated remains), and the absence of well-preserved megalonychid remains in other coeval units of South America, a systematic review of the species in a cladistic and evolutionary context is difficult to perform (see Brandoni, 2011). Nevertheless, the study of the genera and species recorded in the Late Miocene of Argentina could be useful for inferring some chronological and biogeographical relations for the Cenozoic of South America and Central America and Antilles.

\section{ACKNOWLEDGMENTS}

I thank A. Kramarz (MACN) and M. Reguero (MLP) for facilitating access to collections of their institutions. I thank G. De Iuliis and an anonymous reviewer for the comments and suggestions, which improved the quality of this paper. PIP CONICET 00111 partially funded this paper.

\section{REFERENCES}

Aceñolaza, F.G. 1976. Consideraciones bioestratigráficas sobre el Terciario marino de Paraná y alrededores. Acta Geológica Lilloana, 13:91-107.

Ameghino, F. 1883. Sobre una nueva colección de mamíferos fósiles recogidos por el Profesor Pedro Scalabrini en las barrancas del Paraná. Boletín de la Academia Nacional de Ciencias de Córdoba, 5:257-306.

Ameghino, F. 1885. Nuevos restos de mamíferos fósiles Oligocenos recogidos por el Profesor Pedro Scalabrini y pertenecientes al Museo Provincial de la ciudad de Paraná. Boletín de la Academia Nacional de Ciencias de Córdoba, 8:5-207.

Ameghino, F. 1887. Enumeración sistemática de las especies de mamíferos fósiles coleccionados por Carlos Ameghino en los terrenos eocenos de la Patagonia austral y depositados en el Museo de La Plata. Boletín del Museo de La Plata, 1:1-26.

Ameghino, F. 1891a. Mamíferos y aves fósiles argentinos. Especies nuevas, adiciones y correcciones. Revista Argentina de Historia Natural, 1:240-259.

Ameghino, F. 1891b. Nuevos restos de mamíferos fósiles descubiertos por Carlos Ameghino en el Eoceno inferior de la Patagonia austral. Especies nuevas, adiciones y correcciones. Revista Argentina de Historia Natural, 1:289-328.

Anthony, H.E. 1926. Mammals of Porto Rico, living and extinct. Rodentia and Edentata. New York Academy of Sciences/ Scientific Survey of Porto Rico and West Islands, p. 97-241.

Bargo, M.S.; Vizcaíno, S.F. \& Kay, R.F. 2009. Predominance of orthal masticatory movements in the early miocene Eucholaeops (Mammalia, Xenarthra, Tardigrada, Megalonychidae) and other megatherioid sloths. Journal of Vertebrate Paleontology, 29:870880. doi:10.1671/039.029.0324

Bordas, A.F.1942. Observaciones sobre algunos Nothrotheriinae (Gravigrada). Physis, 19:173-179.

Brandoni, D. 2006. A review of Pliomegatherium Kraglievich, 1930 (Xenarthra: Phyllophaga: Megatheriidae). Neues Jahrbuch für Geologie und Paläontologie, Monatshefte, 4:212-224.

Brandoni, D. 2008. Nuevos materiales de Ortotheriinae (Xenarthra, Tardigrada, Megalonychidae) procedentes del "Mesopotamiense" (Mioceno tardío) de Entre Ríos. In: F.G. Aceñolaza (ed.) Temas de la Biodiversidad Fluvial del Litoral III, INSUGEO, p. 11-20 (Miscelánea 17).

Brandoni, D. 2009. Descripción anatómica del fémur de Protomegalonyx chasicoensis Scillato-Yané (Mammalia, Xenarthra, Megalonychidae) procedente la Formación Arroyo Chasicó (Mioceno tardío), de la provincia de Buenos Aires, Argentina. Ameghiniana, 46:513-521.

Brandoni, D. 2010. On the systematics of Ortotherium Ameghino (Xenarthra, Tardigrada, Megalonychidae) from the "Conglomerado osífero" (late Miocene) of Argentina. Journal of Vertebrate Paleontology, 30:975-980. doi: 10.1080/02724631003763474

Brandoni, D. 2011. The Megalonychidae (Xenarthra, Tardigrada) from the late Miocene of Entre Ríos Province, Argentina, with remarks on their systematics and biogeography. Geobios, 44:3344. doi: 10.1016/j.geobios.2010.06.005

Brandoni, D. 2013a. Los Tardigrada (Mammalia, Xenarthra) del Mioceno Tardío de Entre Ríos, Argentina. In: D. Brandoni \& J.I. Noriega (eds.) El Neógeno de la Mesopotamia argentina, Asociación Paleontológica Argentina, p. 135-144 (Publicación Especial 14). 
Brandoni, D. 2013b. Los mamíferos continentales del "Mesopotamiense" (Mioceno tardío) de Entre Ríos, Argentina. Diversidad, edad y paleobiogeografía. In: D. Brandoni \& J.I. Noriega (eds.) El Neógeno de la Mesopotamia argentina, Asociación Paleontológica Argentina, p. 179-191 (Publicación Especial 14).

Brandoni, D. 2014. “Xyophorus” sp. en el Mioceno Medio de Chubut: implicancias sistemáticas, biogeográficas y biocronológicas del registro de un Nothrotheriinae en el Neógeno de la Argentina. Ameghiniana, 51:94-105. doi:10.5710/AMGH.05.12.2013.1267

Brunetto, E.; Noriega, J.I. \& Brandoni, D. 2013. La Formación Ituzaingó en la provincia de Entre Ríos. Estratigrafía y edad. In: D. Brandoni \& J.I. Noriega (eds) El Neógeno de la Mesopotamia argentina, Asociación Paleontológica Argentina, p. 13-27 (Publicación Especial 14).

Carlini, A.A. \& Scillato-Yané, G.J. 2004. The oldest Megalonychidae (Xenarthra: Tardigrada); phylogenetic relationships and an emended diagnosis of the family. Neues Jahrbuch für Geologie und Paläontologie, Abhandlungen, 233:423-443.

Carlini, A.A.; Scillato-Yané, G.J.; Noriega, J.I. \& Aceñolaza, F. 2000. Perezosos terrestres (Xenarthra, Tardigrada) del "Mesopotamiense" (Fm. Ituzaingó, Mioceno tardío-Plioceno) de la Provincia de Entre Ríos, Argentina. Studia Geologica Salmanticensia, 36:13-27.

Cione, A.L. et al. 2000. Miocene vertebrates from Entre Rios Province, eastern Argentina. Tucumán, INSUGEO, p. 191-237 (Serie Correlación Geológica 14).

De Iuliis, G.; Gaudin, T.J. \& Vicars, M.J. 2011. Anew genus and species of nothrotheriid sloth (Xenarthra, Tardigrada, Nothrotheriidae) from the Late Miocene (Huayquerian) of Peru. Palaeontology, 54:171-205. doi:10.1111/j.1475-4983.2010.01001.x

Frenguelli, J. 1920. Contribución al conocimiento de la geología de Entre Ríos. Boletín de la Academia Nacional de Ciencias de Córdoba, 24:55-256.

Gaudin, T.J. 2004. Phylogenetic relationships among sloths (Mammalia, Xenarthra, Tardigrada): the craniodental evidence. Zoological Journal of the Linnean Society, 140:255-305. doi: 10.1111/j.1096-3642.2003.00100.x

Gradstein, F.M.; Ogg, J.G. \& Hilgen, F.J. 2012. On the Geologic Time Scale. Newsletters on Stratigraphy, 45:171-188.

Hirschfeld, S.E. \& Webb, S.D. 1968. Plio-Pleistocene megalonychid sloths of North America. Bulletin of the Florida State Museum, 12:213-296.

Kraglievich, L. 1922. Amphiocnus paranense n. gen., n. sp. Un probable precursor del Megalocnus de la isla de Cuba en la Formación Entrerriana. Physis, 6:73-77.

Kraglievich, L. 1923a. Un probable descendiente directo del género Hapalops del Oligoceno de Patagonia en la fauna miocena de Entre Ríos. Neohapalops rothi, n. gen., n. sp. Comunicaciones del Museo Nacional de Historia Natural de Buenos Aires, 2:9-16.

Kraglievich, L. 1923b. Descripción de dos cráneos y otros restos del género Pliomorphus Ameghino procedentes de la Formación Entrerriana de las barrancas del Río Paraná. Anales del Museo Nacional de Historia Natural de Buenos Aires, 33:1-56.

Kraglievich, L. 1923c. Un nuevo representante de la subfamilia Ortotheriinae en la Formación Entrerriana de las barrancas del río Paraná. Torcellia paranense, n. gen., n. sp. Comunicaciones del Museo Nacional de Historia Natural de Buenos Aires, 2:2-8.

Kraglievich, L. 1925. Un nuevo eslabón en la serie filogenética de la Subfamilia Nothrotherinae: Senetia mirabilis. Nuevo género y especie de la Formación Entrerriana. Anales del Museo Nacional de Historia Natural de Buenos Aires, 33:177-193.
Kraglievich, L. 1926a. Notas sobre gravígrados de Sud América. Anales del Museo Nacional de Historia Natural de Buenos Aires, 34:21-36.

Kraglievich, L. 1926b. Presencia del género “Nothrotherium” Lydek (= "Coelodon" Lund) en la fauna pampeana Nothrotherium torresi, n. sp. Revista del Museo de La Plata, 29:169-186.

Kraglievich, L. 1930. Nuevos megalonícidos gigantescos de los géneros Megalonychops Kragl. y Diheterocnus Kragl. Revista del Museo de La Plata, 32:9-21.

MacPhee, R.D.E.; White, J.L. \& Woods, C.A. 2000. New megalonychid sloths (Phyllophaga, Xenarthra) from the Quaternary of Hispaniola. American Museum Novitates, 3303:1-32.

Matthew, W.D. 1931. Genera and new species of ground sloths from the Pleistocene of Cuba. American Museum Novitates, 511:1-5.

Matthew, W.D. \& Paula Couto, C. de. 1959. The Cuban edentates. Bulletin of the American Museum of Natural History, 117:1-56.

McAfee, R.K. 2011. Feeding mechanics and dietary implications in the fossil sloth Neocnus (Mammalia: Xenarthra: Megalonychidae) from Haiti. Journal of Morphology, 272:1204-1216. doi:10.1002/ jmor. 10976

McDonald, H.G.; Dundas, R.F. \& Chatters, J.C. 2013a. Taxonomy, paleoecology and taphonomy of ground sloths (Xenarthra) from the Fairmead Landfill locality (Pleistocene: Irvingtonian) of Madera County, California. Quaternary Research, 79:215-227. doi: 10.1016/j.yqres.2012.10.007

McDonald, H.G.; Rincón, A. \& Gaudin, T.J. 2013b. A New Genus of Megalonychid Sloth (Mammalia, Xenarthra) from the Late Pleistocene (Lujanian) of Sierra De Perija, Zulia State, Venezuela. Journal of Vertebrate Paleontology, 33:1226-1238. doi:10.1080/02724634.2013.764883

Muizon, C. de \& McDonald, H.G. 1995. An aquatic sloth from the Pliocene of Peru. Nature, 375:224-227. doi:10.1038/375224a0

Pujos, F. \& De Iuliis, G. 2007. Late Oligocene Megatherioidea fauna (Mammalia: Xenarthra) from Salla-Luribay (Bolivia): new data on basal sloth radiation and Cingulata-Tardigrada split. Journal of Vertebrate Paleontology, 27:132-144. doi:10.1671/02724634(2007)27[132:LOMFMX]2.0.CO;2

Pujos, F.; De Iuliis, G.; Argot, C. \& Werdelin, L. 2007. A peculiar climbing Megalonychidae from the Pleistocene of Peru and its implication for sloth history. Zoological Journal of the Linnean Society, 149:179-235. doi: 10.1111/j.1096-3642.2007.00240.x

Pujos, F.; De Iuliis, G. \& Mamani Quispe, B. 2011. Hiskatherium saintandrei, gen. et sp. nov.: an unusual sloth from the Laventan of Quebrada Honda (Bolivia) and an overview of Middle Miocene, small Megatherioids. Journal of Vertebrate Paleontology, 31:1131-1149. doi:10.1080/02724634.2011.599463

Scillato-Yané, G.J. 1977. Un nuevo Megalonychidae (Edentata, Tardigrada) de Edad Chasiquense (Plioceno temprano) del sur de la Provincia de Buenos Aires (Argentina). Su importancia filogenética, bioestratigráfica y paleobiogeográfica. Revista de la Asociación de Ciencias Naturales del Litoral, 8:45-54.

Scillato-Yané, G.J. 1980. Nuevo Megalonychidae (Edentata, Tardigrada) del "Mesopotamiense" (Mioceno Tardío-Plioceno) de la provincia de Entre Ríos. Ameghiniana, 17:193-199.

Scillato-Yané, G.J. 1986. Los Xenarthra fósiles de Argentina (Mammalia, Edentata). In: CONGRESO ARGENTINO DE PALEONTOLOGÍA Y BIOESTRATIGRAFÍA, 4, 1986. Actas, Mendoza, Asociación Geologica Argentina, p.151-155. 
Scillato-Yané, G.J.; Uliana, M.A. \& Pascual, R. 1976. Un Megalonychidae (Edentata, Pilosa) del Plioceno de la provincia de Río Negro (Argentina). Su importancia bioestratigráfica y Paleobiogeográfica. CONGRESO GEOLÓGICO ARGENTINO, 6, 1976. Actas, Buenos Aires, Asociación Geologica Argentina, p. $579-591$.

Scott, W.B. 1903-1904. Mammalia of the Santa Cruz Beds. Part 1: Edentata. Reports of the Princeton University to Patagonia 1896-1899, 5:1-364.

Shockey, B.J.; Salas-Gismondi, R.; Baby, P.; Guyot, J.-L.; Baltazar, M.C.; Huamán, L.; Stucchi, M.; Pujos, F.; Emerson J.M. \& Flynn, J. 2009. New Pleistocene cave faunas of the Andes of Central Peru: radiocarbon ages and the survival of low latitude, Pleistocene DNA. Paleontologia Electronica, 12:1-15.
Stock, C. 1925. Cenozoic gravigrade Edentates of Western North America with special reference to the Pleistocene Megalonychinae, and Mylodontidae of Rancho La Brea. Carnegie Institution of Washington, 331:1-206.

Tauber, A.A. 1997. Paleoecología de la Formación Santa Cruz (Mioceno Inferior) en el extremo sudeste de la Patagonia. Ameghiniana, 34:517-529.

White, J.L. \& MacPhee, R.D.E. 2001. The sloths of the West Indies: a systematic and phylogenetic review. In: C.A. Woods \& F.E. Sergile (eds.) Biogeography of the West Indies, patterns and perspectives, CRC Press, p. 201-235.

Received in June, 2013; accepted in March, 2014. 